\title{
Small states, great power? Gaining influence through intrinsic, derivative, and collective power
}

Article

Accepted Version

Long, T. (2017) Small states, great power? Gaining influence through intrinsic, derivative, and collective power. International Studies Review, 19 (2). pp. 185-205. ISSN 1468-2486 doi: https://doi.org/10.1093/isr/viw040 Available at https://centaur.reading.ac.uk/64707/

It is advisable to refer to the publisher's version if you intend to cite from the work. See Guidance on citing.

Published version at: http://onlinelibrary.wiley.com/journal/10.1111/(ISSN)1468-2486

To link to this article DOI: http://dx.doi.org/10.1093/isr/viw040

Publisher: Wiley

All outputs in CentAUR are protected by Intellectual Property Rights law, including copyright law. Copyright and IPR is retained by the creators or other copyright holders. Terms and conditions for use of this material are defined in the End User Agreement.

www.reading.ac.uk/centaur

\section{CentAUR}


Central Archive at the University of Reading

Reading's research outputs online 


\title{
Small States, Great Power? \\ Gaining Influence through Intrinsic, Derivative, and Collective Power ${ }^{1}$
}

\author{
Tom Long \\ University of Reading; Centro de Investigación y Docencia Económicas
}

It is a good moment in history to be a small state. Small states' survival and territorial integrity are protected by norms, institutions, and the stated policy of the world's strongest power; this situation seems little changed for most small states despite increasing great power competition in Eastern Europe and East Asia. Legal norms of sovereign equality give small states a voice in many international organizations. An open global trading order has allowed many small states to specialize and prosper. Today, the threats to small states are fewer, and the number of small states has increased. Conditions of "democratization, trade liberalization, and reduction of warfare are associated with the formation of small countries" because these conditions promote small states' wellbeing (Alesina and Spolaore 2003:165-67). Another author credited "de-colonisation, de-polarisation, democratisation, deregulation and digitalisation" for the emergence of new polities (Henrikson 2001:65-71). Might the same conditions bolster small states' influence?

If one were to sum up the conventional wisdom on small states, it might be said that while small states are not powerless, when they are confronted directly by a great power, the logic of Thucydides still holds. This article contests that interpretation, to a point, particularly as applied to contemporary international relations. That logic is underpinned by a militarily oriented, resource-based conception of "compulsory power," to use Barnett and Duvall's term (2005:49-51). That approach to power is deeply embedded in the study of small states, and indeed, in the many and contested definitions of "small state." However, as IR scholars have

\footnotetext{
${ }^{1}$ Author's note: Tom Long is a lecturer in International Relations at the University of Reading and an affiliated professor at the Centro de Investigación y Docencia Económicas in Mexico. He would like to acknowledge helpful and constructive comments from two anonymous reviewers and the editors of ISR. A previous version of this paper was presented at the 2015 International Studies Association conference; feedback from participants including Lawrence Rubin, Anders Wivel, and Melissa Mavris helped improve subsequent versions.
} 
long recognized, brute quantifications of resources are an inadequate metric for many issues in world politics. Even in the military field, great powers may topple governments if they are willing to make a major effort, but then find definitive victory elusive. Possessing resources still matters, but it is less determinate than the great power/small state dichotomy leads one to believe. As a classic book noted, small states are as powerful as their "capacity to achieve intended results," and at times, "other factors outweighed their material weakness" (Rothstein 1968:3, 20).

Several years ago, the introduction to a volume on small states noted that, "small states are often treated as objects, not as subjects of international relations" (Neumann and Gstöhl 2006:19). In fact, work on small states has alternated between emphasizing constraints and limitations on the one hand and independence, resilience, and even power on the other. In postCold War IR scholarship, the focus on small states' possibilities has grown more prevalent. This emphasis does not only reflect more auspicious international conditions; divergent perceptions of small states implicitly reflect different conceptualizations of what it means to exercise power in international relations. First, though, a clarification is needed about the term "small state." The literature lacks a common definition or set of criteria to define who counts as "small" (Henrikson 2001:56-65; Maass 2009:65-68). Even among states that intuitively fit the category, the differences can be stark. How can states as diverse as Honduras, Lesotho, Singapore, and Switzerland fit into the same theoretically relevant category? Without clear cut-off points, studies on small states have included Turkey and Spain on the one hand (see Fox 1959) or been limited to island microstates on the other (Mohammed 2013). State "size" clearly exists along a continuum, which does little to distinguish who is "small" and who is not. Building on an approach from Steinmetz and Wivel (2010), Rostoks (2010), and Long (2016), this article places states in the context of asymmetrical relationships. "Relational power or, to be more precise, relational weakness is the main characteristic of small states" (Rostoks 2010:87). This differs from definitions that seek an upper limit on smallness or create fixed categories via qualitative measures (Maass 2009:74-80; Rickli 2008:309). While useful categories of state size have proved elusive, creating categories of behaviors can help scholars understand the dynamics of 
asymmetrical relationships from the perspective of the weaker state. ${ }^{2}$ This article proposes three forms of power that are available and particularly relevant to small states: particular-intrinsic, derivative, and collective power. All states, small or large, can either try to exploit their internal resources or turn to other states. However, because small states, by definition, lack more traditional forms of power, they must specialize in how they employ their resources and relationships. Small states depend more heavily on external options, whether a special relationship with a great power or other small states. This taxonomy explains the three forms of power according to their base, scope, means, and amount (Dahl 1957), which connects small states to broader debates around power in IR.

The first section of the article examines the changing concepts of power employed in the study of small states. To some extent, these reflect broader debates about power in IR, though resources and compulsory power dominated until recently. The article then develops the taxonomy mentioned above by specifying the base, scope, means, and amount of the different types of power, and explaining these in relation to diverse concepts of power. In conclusion, the article addresses how these categories are particularly relevant to small states. Many small states are thriving in a world that is more open and democratic, where the threat of force has receded somewhat and has proven less effective. Non-traditional facets of power are central for states that lack coercive instruments, but they are increasingly relevant for all states.

\section{Concepts of Power in Studies of Small States}

Power remains both a central and contested term in International Relations. Guzzini (2005:495) argues that "the meaning of power is always embedded in a theoretical context." That is no less true in the case of power and the small state. As Berenskoetter (2007) notes, the concept of power in IR has been dominated by realism - at the very least, the debate has occurred on realists' terms. Defined by their very weakness, small states struggled to gain respect in IR, a field long focused on the international competition for power. Goetschel (1998:13) colorfully writes: "Small states were seen as fragile creatures in the rough sea of international relations. They were internally well suited for democratic regimes but externally helpless and constantly

\footnotetext{
${ }^{2}$ Elsewhere, I have suggested the terms "preponderant power" and "hypo-power" to describe states in asymmetrical relationships (Long 2016). Here, I continue to use the more common term "small state" in an attempt to connect with that literature.
} 
threatened by extinction." That view, never unanimous, has waned further in the last two decades, even as the number of small states has grown. Instead of assuming dependence and weakness, even vis-à-vis a great power, currents in the literature on small states increasingly explore opportunities for autonomy and influence. More pluralistic approaches to power offer greater possibilities for positively evaluating small states.

The "small states" literature is diverse, and in a sense united through the use of that term (though small power, weak state, weak power, etc., have been used interchangeably). The literature incorporates several currents that do not always interact: developed versus underdeveloped, European versus non-, economics versus security. A thorough review of each of these literatures is beyond the scope of this piece, and has been admirably tackled by others (Baldacchino 2009; Maass 2009; Neumann and Gstöhl 2006). Instead, this section explores the literature in light of the concepts of power that undergird perceptions of small states' vulnerability or resilience, impotence or importance. Foregrounding these diverse concepts of power illustrates why attempts to define "small state" have often fallen into the inverse of Dahl's "lump of power fallacy." Small states have been defined as a "lump of weakness," which does not recognize their ability to exercise power, even if limited to specific issues, geographies, or relationships. "The traditional definition is simply unable to explain the influence Small Powers have come to exert in world politics," Rothstein (1968:21) argued five decades ago. The realities of both small states and power are more complex. As Rostoks (2010:88) notes, "Luckily enough, from the viewpoint of small states, exercise of power is more complicated than the mere ability of the strong to get what they want." The following section highlights how influential conceptions of power relate to work on small states.

\section{Power as material resources}

The notion that power and influence in world politics are fundamentally based on the possession of certain material resources has deep roots and still exercises great sway. Resourcebased definitions of power facilitate quantification and prediction. For some theorists, primarily realists, the possession of resources is power. Morgenthau and Mearsheimer both employ this approach to power, though neither ignores that the ultimate purpose of power is to change the behavior of other actors (Mearsheimer 2001:57-76; Morgenthau and Thompson 1985:145-63). Material resources are often associated with what Barnett and Duvall (2005:49) call "compulsory 
power," though they are far from the same. It is often assumed that possession of resources is related to the ability to change others' behavior. This assumption undergirds the focus on resources as an indicator of power or as power itself, despite the well-known difficulties of translating resources to capabilities and capabilities to "power over" another actor. Great powers struggle in wars against small ones, as well as against non-state actors (Mack 1975; Maoz 1989; Sullivan, 2007). Power resources are rarely fungible (Baldwin 1979:174).

The very definition of "small state" has typically been based on the amount of resources the small state possesses - that is, not very many. If population, GDP, territory, and military resources make a power "great," it is the lack of these same qualities that makes a state "small." Assessing the myriad definitions of "small state," Maass (2009:74-76) referred to this as the quantitative approach. Several prominent scholars have advanced such definitions (East 1973:557; Ólafsson 1998:8-10; Vital 1967:8-9), but quantification's intuitive appeal is undermined by seemingly arbitrary numerical cutoffs. "The weak and powerful states have many common characteristics and problems. Any attempt to separate out weak states as a totally different 'breed' is artificial" (Handel 1981:190). Even when power is treated as resources, small states are not helpless, particularly in economic terms. Small states may produce crucial commodities, which can serve as an important base of power for even very small states. Strategic location can also function as a resource for small states - though perhaps one that cuts both ways - as seen in Switzerland's defensive posture or Singapore's influence on regional shipping.

\section{Power and structures, agendas, and interests}

The relationship between power and structures is important in rationalist, critical, and constructivist schools of IR. Neorealism, as Wendt (1987:335) noted, defines structure as the distribution of capabilities and treats structure as a constraint of states' choices. In a neorealist world, the opportunities for small states would be limited (Ingebritsen 2006:26-29). Following Waltz (1979), much work argued that anarchy created a dire situation for small states (Hey 2003a:6). Employing an essentially realist concept of power, Vital (1967) concluded that, given external constraints and threats, small states could rarely be truly independent. International structures made it too perilous; passivity or alliance was the likelier - and safer - route. After all, if great powers are constantly preoccupied with survival, the threat to small states' integrity and independence must be even graver. From this vantage, different structures of polarity pressure 
small states in different ways. In a bipolar world, the weight of small states means little to either bloc. Incentives to bandwagon will be increased and possibilities to gain influence by shifting sides will be reduced. As Rothstein (1968:14-15) argued, different configurations of power impact small states' security and room for maneuver. This view was not unanimously held. Keohane (1969) noted that Vital significantly limits what he considers independent foreign policy to a near-ideal type of an unaligned small state that acts alone. Where Vital stresses systemic forces as constraining, Handel points to small states' impressive ability to overcome their vulnerabilities, adapt to changing conditions, and survive.

Critics of realist concepts of structures and power have noted that the effects of power are not always visible; power can be reflected in agendas and "non-decisions" (Bachrach and Baratz 1962), in how weaker actors define their own interests (Lukes 1974), or in structures that shape frameworks and guide processes (Strange 1987). Small states' objectives may be constrained by external structures or shaped by hegemonic institutions and "common sense" (Cox 1983; Cox 1981). These concepts of structural power would seem to limit small states to an even greater extent. After all, the powerful create structures and control agendas. Ingebritsen (2000:28) noted, "According to structural theorists (Waltz, Keohane, and Wallerstein), the Nordic states should have relatively few options given their position in the international system." If that is the case for Nordic and European states, structural theories describe even poorer prospects for small states outside the wealthy, Western world. Drawing inspiration from dependency and world systems theories, applications of an economic-structural concept of power have often focused on small states of the "global south" (Braveboy-Wagner 2003:7-10). The options available to these states are structured by their long-term economic and political dependency on great powers (Moon 1983:333-34). They are doubly marginalized by their peripheral status and their small size (Ayoob 2003; Escudé; 1998; Persaud, 2001). Starting in the mid-1980s, studies and conferences of the Commonwealth Secretariat increased attention to the economic problems of small island states. The Commonwealth (1985) emphasized small-state "Vulnerability" to a host of problems, and advanced a concept of resilience, not power, as a solution. Under the framework of "global south foreign policy," Braveboy-Wagner and Snarr (2003:57) argue that due to their position in global structures, "these states are for the most part still poor, weak, underdeveloped, peripheralized in global institutions, and lack the material power (defined through wealth or the means of violence) to bring about systemwide change in their own interests." 
The focus on economic structures and their links to power has not been limited to critical scholars. Krasner (1976:319) argued that while powerful states determined global economic structures, "Trade gives small states relatively more welfare benefits than it gives large states," though with potentially greater impacts on social stability. Katzenstein (1985) concluded that some small European states had found successful models for adapting to these challenges. Recent work illustrates how many small states have effectively adapted to the U.S.-led economic order. Alesina and Spolaore (2003:81) note that globalization has partially offset the disadvantages of limited market size and low economies of scale. "Size and prosperity do not seem to go hand in hand.” Economic analysis by Easterly and Kray (2000) indicates that small states are, on the whole, better off than larger ones (see also Armstrong and Read 1998), especially if they are deeply engaged in the global economy. Alesina and Spolaore (2003:197) posit that "smaller countries benefit from open trade regimes, so as small countries emerge, it is in their interest to press for more open trade regimes." Small states could gradually shift global economic structures to favor their interests. Globalized economies and "safer" international environments favor the creation of smaller politics units.

While often seen as lending themselves to even deeper great-power dominance, the second and third faces of power can illuminate nonmaterial exercises of power both directed at and led by small states. Following Cox, critical scholars have argued that structures affect both interests and agendas, as discussed below, in part through hegemonic ideologies (Berenskoetter 2007:10-15; Cox 1981, 1983). Deeper structures do not just constrain the decisions of weaker states, but shape their identities, interests, and possibilities for action. The approach to structural power in Barnett and Duvall (2005:52-55) is somewhat different. While structures shape the identity and interests of small states, these are relationships of mutual constitution. Great powers, too, are defined by their structural positions. Structures "allocate differential capacities, and typically differential advantages, to different positions" and "shape self-understanding and subjective interests" (53). The effects of structures are not unidirectional; agents - even relatively weak ones - replicate and perhaps alter structures. Great powers are constituted as such in relation to small states, and they gain privileges through their favored position. Small states' structural positionality may offer distinctive advantages. Extending Barnett and Duvall's concept, it is important to note that small states' interests should not be assumed to replicate those of great powers. Instead, small states' interests will be affected by mutually constituted 
structures, and thus may be affected by great powers even when there is no discrete, observable instance of control. Constructivists have emphasized social and ideational structures of norms and culture (Checkel 1998:332-34). Regarding small states, particularly those in the EU, constructivists highlight avenues to influence through agendas and discourses (Björkdahl 2008; Jakobsen 2009; Kronsell, 2002). These could either be direct, falling into Barnett and Duvall's structural power, or diffuse, which they label "productive power." In their words, both forms of power "concern how the social capacities of actors are socially produced, and how these processes shape actors' self-understandings and perceived interests" (Barnett and Duvall 2005:55).

Recent work on small states offers examples of both. Jourde (2007:482) shows how "weak African authoritarian states draw on and change the representations that Western powers hold about them," using these interpretations to further their own domestic and international interests. In essence, they redefine their constitutive relationships with more powerful states in a process Jourde refers to as "framing" and "extraversion." At times, these ideational foreign policy strategies are more diffuse and mediated through institutions. Examining disputes between small states and international organizations over tax policy, Vlek (2009) illustrates how the OECD and Caribbean states rhetorically jousted over "tax havens." Bailer (2004) has argued that states use both positioning and proximity to agenda-setters to advance their preferred positions in EU negotiations. Darnton (2012:64-66) argues that Latin American states may influence the agenda while the United States focuses elsewhere; when U.S. attention returns, Latin American leaders advance preferred interpretations and solutions. While structures and agendas may constrain the small, these non-material aspects of power also present new possibilities.

\section{Power through interdependence and institutions}

Discussions about power and small states have drawn inspiration from liberal IR theory regarding interdependence and institutions. Interdependence de-emphasizes military force and illustrates the complexity involved in the exercise of power. Keohane and Nye (1973:160-61) stressed that power "cannot be considered a homogenous, highly interchangeable commodity." A liberal, relational approach makes it clear that power - both the ability to change others' behaviors and to resist pressures to change one's own - can vary dramatically across issue areas (Keohane and Nye 1977:91-98). This view of power has been influential in studies of small 
states. Baldwin (1979:164) wrote: 'So-called 'weak powers' influence so-called 'strong powers' because of the power analyst's failure to account for the possibility that a country may be weak in one situation but strong in another." Complex interdependence increases the influence and maneuverability of small states. In oceans and fishing issues, small states gained important influence through international organizations, law, bargaining linkages, and even symbolic uses of force (Keohane and Nye 1977:112-28). By de-emphasizing the military aspects of power, Nye's (2004) more recent concept of soft power opens the door for states to achieve their goals without capabilities for force or coercion. Though Nye has focused largely on the United States, small-state scholars have adopted and modified Nye's concept. Chong (2010) argues that the tiny Vatican and small but robust Singapore use soft power to overcome smallness through "virtual enlargement." Soft power strategies offer another option for states lacking traditional power resources.

As noted above, a variety of evidence demonstrates that small states can be economically successful in an interdependent world. A key argument for Alesina and Spolaore (2003:81-94, 155-174) is that an open trading system allows small states to emerge as viable and successful economic entities. Though they are likely to be asymmetrically dependent on liberalized access to larger states' markets, this has not always allowed large states to bully small ones. Handel (1981:236-256) notes that small states have frequently resisted economic pressures from great powers by shifting their trade patterns. Small, developed states have shown resilience to structural, global market forces and have found niches in the global economy (Katzenstein 1985:21-30). If trade allows some small states to thrive, does interdependence also create avenues for influence? Keohane and Nye (1977:202-204) noted Canada's success in using its complex interdependent relationship with the United States to advance its goals vis-à-vis its powerful neighbor. Great powers, too, may depend on small states to accomplish their objectives, purchase their products, or supply materials. Secondly, scholars have built on liberal IR theory to examine how small states use institutions to enhance security and pursue interests. "International organizations are frequently congenial institutions for weak states," which can use them to build solidarity and coalitions, advance favorable norms, and "pursue linkage strategies" (Keohane and Nye 1977:36). Barnett and Duvall (2005:51) define institutional power as “actors' control of others in indirect ways" such as by forming rules and procedures. While large states have often led efforts to create institutions in world politics, small states frequently turn to 
international law and institutions both as focal points for cooperative efforts and as a means to limit the unilateralism of great powers. As such, institutions can be understood both as a site for the exercise of power, as in much of the literature on small states in the EU, and as a means for both power-over and power-with.

Goetschel (1998) asked, if small states were no longer forced to concentrate on their survival, how would they act? How would they affect, and be affected by, processes of integration? These questions have been central in Europe, where many scholars argue that small countries have been able to "punch above their weight" because of institutional arrangements that grant them a greater degree of influence and voice. Luxembourg has been a founding, model member of European institutions, and it has used this to pressure for favorable EU policies, while seeking to strengthen institutions as a bulwark against historic German-French rivalry (Hey 2003b). Ingebritsen (2002:383) argues that small European states opted to pool sovereignty in European institutions both in the quest for regional prosperity and to enhance European influence vis-à-vis the United States. Small states have "a greater capacity to influence the agenda in world politics and play a critical role in the evolution of European integration than is commonly understood" (Ingebritsen 2004:369-70). Inside European institutions, small states can construct "a position of authority" through diplomacy and administrative excellence. Panke (2011:135-37) argues that despite disadvantages, small states are often effective participants in EU negotiations, prioritizing among and within institutions to gain an impact where it matters most. Small states have pressed to maintain and create favorable rules and voting procedures inside the EU, such as a presidency that grants small states relatively significant influence (Thorhallsson and Wivel 2006:660-64). There is evidence that "The commission's positions tend to favor small and medium member states slightly more than large member states" (Thomson 2008:190). In European security, Rickli (2008:310-11) argues that small states must choose between autonomy and influence through alliance, but cannot have both. Certainly many have opted for engagement. Baltic states have used membership in NATO to advance security priorities, even before the recent crises with Russia (Hamilton 2008). Institutional designs have important effects on small states, and not surprisingly, these have often pushed for equal voting rights and greater input, a course prevalent in Europe (Ólafsson 1998; Panke 2010; Wivel 2010), but also present elsewhere. However, Rickli's dichotomy overlooks structural and productive aspects of power, and therefore seems to collapse collective and derivative power, as discussed below. Small states 
may seek and use influence precisely to restrain other states and enhance their autonomy. NonEuropean small states sometimes construct and maintain institutions and inter-governmental organizations (IGOs) for these benefits. Singapore plays a central role in the Association of Southeast Asian Nations (ASEAN) and other regional forums (Acharya 2008:23-29). Qatar has enhanced its international visibility through the Gulf Cooperation Council (Kamrava 2013). Latin American states have appealed to international law to limit or delegitimize U.S. interventions (Friedman and Long 2015), while also creating a host of regional and subregional organizations. A coalition of small and medium states from across the globe pushed for the creation of the International Criminal Court, even over objections from large states. The court's statutes give them weight disproportionate to their populations (Bosco 2014:8, 31-40). As Keohane and Nye indicated four decades ago, international institutions can give small states both a forum and a tool for advancing their interests. As Barnett and Duvall note, this often takes a diffuse form; small states seek to influence institutional norms and processes in ways that grant them greater influence.

\section{Power through norms}

The concept of power as related to norms, discourses, and ideas is most closely linked with constructivist IR theory. Ropp and Sikkink (1999:9) discuss the "power of principles;" norms, they argue, can change both interests and incentives. This has been referred to as "normative power" to affect state behavior (Klotz, 1995). More broadly, Manners (2002:32) argued for normative power as "the ability to shape or change what passes for normal in international relations." Because the ability to promote ideas has no necessary relation to state size - after all, the constructivist literature focuses on individuals, NGOs, and IGOs as "norm entrepreneurs" - this form of power has drawn great attention in relation to small states. Perhaps its foremost proponent, Ingebritsen (2002), has highlighted the outsize roles attained by small states, especially in Scandinavia, through the promotion of norms on conflict resolution and environmental protection. Small states have been active mediators and peacekeepers, building norms that delegitimize the use of force (Waage 2007, Kleiboer 1996). While attention to normative power has grown, it is not entirely absent in earlier work on small states. Fox's (1959: 2-3) classic book notes that: 
the ability of a state to secure what it wants through the use of violence is only one mark of political power...small states may have at their command the capacity to appeal to world opinion, operating from a "rectitude" base.

More recently, small states have acted as norm entrepreneurs in various areas. Small and middle powers were instrumental in advancing "norms without great powers" to support multilateral treaties including a ban on antipersonnel land mines (Bower 2015). Small island states have used their particular vulnerability to advance normative claims surrounding climate change (Benwell 2011). Sikkink (2007) has argued that small and middle powers in Latin America played influential roles in advancing specific conceptions of human rights, including economic and social rights in the immediate post-war period, even as great powers were opposed or ambivalent. For the most part, advancing norms is a long-term proposition for smaller states. That is, through changing international norms, smaller states do not seek to affect one particular outcome - a usage somewhat distinct from Klotz's original term. Instead, they seek to reshape the international environment in ways that favor behaviors that are more beneficial to them. Norms against unilateral intervention represent a significant victory for smaller states. Broadly oriented efforts to shift international norms fit within Barnett and Duvall's "productive power," by seeking to reconstitute diffuse aspects of international social relations (2005:55-57).

\section{Bases and Means of Small States' Power}

The concept of "small state" has long been defined according to a particular conception of power - power as possession of particular, material resources. However, in a world where the anxiety about survival has decreased and where military coercion no longer clearly dominates the hierarchy of power, the conceptualization of both power and the small state are open to reinterpretation. Other ways of understanding power open analysts' eyes to the possibility of greater influence from states long termed "small."

Dahl's work on power is most often remembered for his classic formulation: "A has power over B to the extent he can get B to do something that B would not otherwise do" (Dahl, 1957:202-03). In the same piece, Dahl adds that what is more interesting than specifying the actors in a power relationship (that A has power over B) is to analyze the base, means, amount, and scope of one actor's power over another. The following taxonomy uses that framework to 
assess the ways in which small states - lacking the traditional bases of power - specialize in other bases and means of power. According to Dahl, "The base of an actor's power consists of all the resources - opportunities, acts, objects, etc. - that he can exploit to effect the behavior of another." The means involve how an actor utilizes its base, such as through threats and promises. “Thus the means is a mediating activity by A between A's base and B's response." The scope involves the range of B's responses that A can influence. The amount of power for Dahl is probabilistic - what are the chances that A's actions will change B's behavior (within a given scope)? Dahl (1957:203-06) also suggests that analysts should consider the number and type of actors who will respond to A's power. When analyzing small states, the framework is useful in moving the analyst away from the dominant focus on a handful of resources as the "base" of state power. A small state might have different sources of power, differently exercised, to varying degrees, across a range of issues. While not exclusive to small states, these alternate forms of power are likely to receive greater emphasis from those lacking traditional bases of power, perhaps leading to a greater specialization in their use.

Though Dahl's definition of power has often served as a basis for realists, it does not inherently favor one type of actor (say, great powers) over others. His approach is amenable to studying small states because what matters is less resources possessed than the effects of power. Bases and means do not "provide us with a comparison of the power of two or more actors, except insofar as it permits us to make inferences" about B's responses (1957:206). Dahl's formulation is normally seen as being limited to compulsory power - a direct interaction between specific actors - and that is where Barnett and Duvall place it. Compulsory power is the facet of power most obviously relevant to observing how states, large or small, exercise international influence, particularly via the use of material resources (or bases) most commonly identified with international power. This form of power is thought to translate, at least to some extent, across issue areas, allowing great powers to create linkages and compel and/or incentivize changed behaviors from smaller states. IR's focus on compulsory power has fed into the conventional wisdom that while small states may exercise a degree of influence that seems to exceed their size, when confronted with a great power, they are "ultimately featherweights without a chance to truly beat a heavyweight." 3 However, compulsory power is not necessarily limited to great

\footnotetext{
${ }^{3}$ This phrase was suggested by an anonymous reviewer.
} 
powers, nor are the sources of compulsory power limited to the material (Barnett and Duvall 2005:50). Power is more complex than compulsion for states of all sizes. A broader interpretation of power that is more attuned to its structural, institutional, and productive aspects, suggests additional opportunities for small states. Small states, too, can produce institutions and discourses; their actions can (re)constitute structures.

The following section argues that small states can most successfully pursue their interests through three types of power: derivative power, particular-intrinsic power, and collective power. These categories evaluate small-state "strength in relation to their specific interests and needs" (Handel 1981:257). Though these types of power are not foreclosed to middle or great powers, small states are forced by their limitations to rely on them to a greater extent, developing specific bases and means to be successful. Different small states will possess different material, ideational, and relational bases; they will also have different goals. These discrepancies lead to significant diversity in the means of small states' power, as well as its effectiveness in changing others' behavior (as seen in the amount and scope, in Dahl's words).

\section{Particular-Intrinsic, Derivative, and Collective Power}

Each of the three categories described here can be seen as having a different base, which in turn lends itself to different means. As in any relational conception of power, these two aspects can be understood as properties of small state (A) and its actions. Understanding the amount and scope of power requires the analyst to consider the object of action (B), and to place the exercise of power in a specific context. Because small states - or at least the smaller state in a dyadic sense have relatively scarce international coercive capabilities, they develop particular-intrinsic, derivative, and collective power. These types of power match the bases available to the small state to its goals through the application of certain means. As post-Dahlian approaches to power indicate, these means may be directed at a specific actor(s) or their exercise may be diffuse.

\section{Particular-intrinsic Power}

Power in International Relations, when discussed in terms of capabilities or "potential power," (Copeland 2000:6) is usually synonymous with intrinsic power. Morgenthau's criteria of power were largely intrinsic. Population, territory, GDP, and military strength are all inherent. While there is no agreed upon weighting of these criteria, states are usually understood as great 
powers, middle powers, or small states based on estimates of these factors. Though small states lack many of the normal categories of capabilities, they may possess particular forms of intrinsic power. Particular-intrinsic resources are a potential base of power, but these resources (less so than a tremendous military) only become salient in world politics through their exercise. Not commonly understood as power, the resource fades from view until it is given means and applied to a specific goal, or scope. The amount of power - defined by Dahl as probability of changed behavior - depends heavily on the context in which particular-intrinsic power is deployed.

Examples, even if anecdotal, help illustrate how this form of power matters for small states. Hydrocarbon resources have been the most prominent. On their own, these resources constitute a base of power (and a rather traditional one). Hydrocarbons are not salient, ipso facto, as a way for the possessor (A) to make a targeted state (B) do something that B would not otherwise do. In fact, for the early history of oil production, the British and American exploiters of hydrocarbon resources derived more power from them than the Middle Eastern states that sat atop the oil and gas. These same resources can make states prone to division and strife instead of making them powerful. Internationally, hydrocarbons gain potency through the means employed to deploy the base. Initially, the scope of these actions was narrow - pressuring for greater control and higher prices for those resources. As the context changed, oil states were able to broaden the scope and increase the amount of power they could derive from this resource. The scope of small states' particular-intrinsic power will often start narrowly, but some states may be able to astutely build linkages to pursue broader foreign policy objectives. The combination of base with means provided new power to a number of small states - making formerly marginal states central to world politics. All but three of OPEC's twelve active members have populations under thirty million, but in the current context, resource control gives them greater influence singly and together (more on that shortly). Outside of OPEC, Braveboy-Wagner (2010) discusses how very small Trinidad and Tobago is able to deploy its reserves of natural gas to gain influence and pursue its goals in the Caribbean.

Particular-intrinsic power is not limited to oil and gas producers. Panama's control over its isthmian canal lets it play a larger role than its Central American neighbors in a host of issues related to global commerce. Even with the Canal under U.S. control, Panama was able to use its territoriality to effect major changes in U.S. policy - though doing so took nearly a decade (Long 
2014). Military power, long the sine qua non of international power, is not the exclusive preserve of great powers, either. Countries as different as Switzerland and Singapore have invested in outsize forces that can deny larger neighbors access and influence; both states have unique geographical locations that have encouraged this strategy (Acharya 2008:14-17; Fox 1959:5-6). Though great powers may have once preferred to directly control strategic locations (like Singapore), they have largely opted for lower-cost strategies (Desch 1993:12). After 2001, this allowed Central Asian states to play great power rivalries for greater benefits, including military and economic assistance, that bolstered domestic control and boosted international influence (Cooley 2014:20-21). Small states that possess these strategic locations therefore hold a base of particular-intrinsic power.

As with great powers that use their intrinsic resources via a sticks-and-carrots approach, compulsory power is the most immediately visible aspect of particular-intrinsic power. It can both be broader and complementary to other forms of power. Particular-intrinsic power can grant a state a central position in an international organization, allowing it to shape rules (institutional power). It may also shape the constitution of a relationship between a small state and a great power (structural power). Particular-intrinsic power can combine material and ideational resources. Identity can serve as a base for the exercise of power. Following constructivist insights, identity is mutually constituted, and therefore is not under the total control of the actor with that identity. This lends identities a degree of stability; while they are malleable, they are not easily or unilaterally altered (Hopf, 1998:174-77). However, the words and actions of a small state - its performances - along with the perceptions of others, help construct that small state's identity and shape its relations with other states (Jourde 2007). Given this ideational base, it can take actions (means) that will be at least partially interpreted in light of that identity. For example, Scandinavian countries have gained fame as promoters of international norms on mediation of conflicts and sustainable development (Ingebritsen 2002:11-23). This identity emerges from intersubjective understandings of these countries' domestic societies and foreign policies. It has allowed these states to emerge as models for the resolution of conflicts (Jakobsen 2007). Finland has developed an identity not as small but as smart and innovative (Browning 2006). These particular-intrinsic resources are based in identity, but states may deploy them through various means in exercises of direct or diffuse power. Qatar, building on the wealth derived from its natural gas, developed an identity as a hub for globalization, as the center of 
communications, air travel, and financial networks. While the material bases of power are important, the changed perception of Qatar has allowed it to play an outsize role in regional conflicts and global economics (Kamrava 2013:61-68). Cuba, since 1959 a hyperactive smallstate par excellence, has developed a number of notable and unconventional bases of particularintrinsic power. These include world-class medical capabilities, particularly in vaccine research and the treatment of tropical disease (Jiménez 2011, 2013), and widely admired sports and sports-training programs (Huish 2011; Kirk 2009). Cuba has been able to employ these bases to work toward foreign policy goals that range from gaining subsidized energy concessions to advancing counterhegemonic South-South cooperation through both institutions and diffuse norms. During the Cold War, it also developed conventional capabilities - though these were unconventional for a state its size - deploying covert and overt military power "to make a world safe for revolution," (Dominguez 1989). Cuba's great-power-sized foreign policies drew on Soviet support, but essentially reflected Cuba's own goals and particular-intrinsic power (Gleijeses 2008).

\section{Derivative Power}

Lacking significant material capabilities of their own, small states may derive power by convincing larger states to take actions that boost their interests. This has often been seen as the primary option for small states, described by Keohane (1971) as "the big influence of small allies." The United States' open, pluralistic foreign policy decision-making process allowed small state leaders to appeal to U.S. missionary zeal or court narrow bureaucratic interests. Small states' derivative power is not limited to relations with the United States. Fox (1959:45) wrote that, "The strength of the small states was thus 'other-conditioned' and therefore inherently unstable, depending as it did upon the existing relationships between the great powers." Handel (1981:257), who employed the term "derivative," considered this the most important facet of small states' strength. "The diplomatic art of the weak states is to obtain, commit, and manipulate, as far as possible, the power of other more powerful states in their own interests." Through the use of derivative power, the leaders of small states seek to act as the proverbial tail that wags the dog. However, it is not an unalloyed strength. Scholars and statesmen starting with Machiavelli have warned small-state leaders against allying with a great power: "an unequal 
alliance provides the small power with only a limited potential for achieving goals. It has little leverage to exert against its stronger ally" (Rothstein 1968:122).

Derivative power poses a conceptual challenge for orthodox approaches to power. At first glance, it does not seem to have any base at all. However, following Barnett and Duvall, the base of derivative power can be understood as the constitutive relationship between small ally and great power. If one accepts that power is about social relations, those relations may also form a source of power. The means of derivative power will vary according to the small state's goals and its relationship with the great power. In a particularly friendly relationship, smaller powers might gain access to policy discussions. Risse-Kappen (1995:198-206) argues that in some cases, NATO countries were seen by the United States almost as additional bureaucratic actors with substantial input in debates. Keohane (1971:165-166) describes small states like Portugal leveraging their influence over the branches of the U.S. military to achieve broader policy objectives or to extract resources. In a pluralistic system, small states might be able to launch campaigns to influence policy through co-ethnic or ideological supporters, including through legislative lobbying (DeConde 1992; Mearsheimer and Walt 2007; Newhouse 2009). In more contested relationships - depending on the international context - small states have engaged in "patron alliance manipulation," by threatening to defect (Carney 1989; Jourde 2007:484). This could be done in order to draw funding or military equipment, or to gain support against domestic or regional rivals. Carney (1989) treats these as patron-client relationships in which the smaller state is rewarded for compliance. Lake (2009:45-62) makes a similar characterization of what he terms "hierarchical" relationships; commands from the large state are recognized as legitimate by the small state, even if these relationships are often contested. However, when a "client" can help a patron achieve a significant goal, the small state can exact a significant price (Shoemaker and Spanier 1984:17-18). Fox (1959) argued that small states played alliances in order to stay on the margins of World War II. This type of derivative power is rooted in structural, not compulsory, aspects. Small states may reconstitute a relationship in ways that make their cooperation (submission in Lake's terms; compliance in Carney's) valuable through ideological, strategic, or material means. Clients - not just the patron - define the relationship.

Derivative power is likely to have a narrow scope. It is impractical for a small state to try to change the overall disposition of a great power. However, it may be possible to change the 
great power's policy on a specific matter of interest to a small power. As scholars of interdependence, starting with Keohane and Nye (1977) have argued, given that questions of central and intense interest for a small state might be peripheral to a great power with global concerns, these seemingly minor changes of policy can be overwhelmingly important for a small demandeur. Put differently, asymmetries in material power may be somewhat offset by asymmetries in interest intensity and expertise that favor the smaller state. A small change in U.S. economic or military assistance could amount to a significant portion of the state budget for a small, low-income state, and might tilt the balance between domestic or regional rivals. As Keohane (1969:310) concluded, "If Lilliputians can tie up Gulliver, or make him do their fighting for them, they must be studied as carefully as the giant."

The advantage of derivative power is that it offers the possibility of amplifying a small state's influence through the prism of a great power - though with a concomitant decline in control over outcomes. In Dahl's framework, derivative power can offer small states a much greater amount of power over a third party, and perhaps at a lower cost. In practice, empirically establishing derivative power requires a scholar to address the implicit counterfactual that, absent the influence of the small state, the great power would not have taken the course of action that it chose. Asserting the amount of power that owes to a given small state is harder still and is likely to require careful process-tracing. Only a handful of studies have attempted to address the question directly. Colombia has used its relationship with the United States to gain the upper hand in its internal conflict, and at times to strengthen its position vis-à-vis neighboring Venezuela. One scholar termed the U.S.-Colombian relationship "intervention by invitation" (Tickner 2007). Small powers have long tried to protect their safety or gain regional advantages through effective use of alliances (Rothstein 1968). U.S. support has been crucial to Taiwan's continued independence and for Israel's military and economic strength. While larger states also try to accomplish their objectives through third parties, derivative power is an essential approach for the small state. Based on relationships with a larger state, this form of power offers the opportunity for a small state to pursue and perhaps accomplish major objectives that could otherwise be beyond its grasp.

\section{[INSERT TABLE 1 HERE]}




\begin{tabular}{|c|c|c|c|}
\hline \multicolumn{4}{|c|}{ Table 1: Three Categories of Power } \\
\hline & Particular-intrinsic & Derivative & Collective \\
\hline Base (source) & $\begin{array}{l}\text { Resource inherent to } \\
\text { small state }\end{array}$ & $\begin{array}{l}\text { Relationship with } \\
\text { great power }\end{array}$ & $\begin{array}{l}\text { Relationships with } \\
\text { smaller powers }\end{array}$ \\
\hline $\begin{array}{l}\text { Means } \\
\text { (instrument) }\end{array}$ & $\begin{array}{l}\text { Threat/promise to } \\
\text { withhold or grant }\end{array}$ & $\begin{array}{l}\text { Lobbying, framing, } \\
\text { patron alliance } \\
\text { manipulation }\end{array}$ & $\begin{array}{l}\text { Institutional; ad hoc } \\
\text { coalitions }\end{array}$ \\
\hline $\begin{array}{l}\text { Amount } \\
\text { (extent) }\end{array}$ & $\begin{array}{l}\text { Contextually } \\
\text { dependent }\end{array}$ & Potentially great & Depends on coalition \\
\hline Scope (range) & $\begin{array}{l}\text { Directly related to } \\
\text { resource, plus } \\
\text { linkages }\end{array}$ & Issue specific & $\begin{array}{l}\text { Narrow for ad hoc } \\
\text { coalitions; diffuse for } \\
\text { institutions }\end{array}$ \\
\hline
\end{tabular}

\section{Collective Power}

If the fundamental base of derivative power is the relationship between the small state and a great power, the fundamental base of collective power is the relationship between a small state and associated non-great powers. It is not surprising that small states might seek strength in numbers, but it has generally been assumed that for these groups to gain significance, they would have to be "so large that each state has minimal influence" (Keohane 1969:296). Rothstein (1968:170-178) notes the limited successes of the Little Entente, but is ultimately skeptical of small power alliances, at least in a military sense. However, small states' collective power can work in different ways: through dedicated institutionalism, via single-issue groupings, or to leverage allies for one state's cause. In Barnett and Duvall's taxonomy, collective power could be either compulsory or institutional. It is compulsory in cases when a grouping of small states directly pressures a larger state to change its policies through threats or promises. More frequently, this will be mediated by institutions that may give some formal protection and voice to small states. Institutions improve small states' ability to influence both primary rules and secondary rules about the processes through which decisions are made. Where institutions are used as a venue for promoting and expanding norms that affect international society more broadly - and are therefore not limited to the interactions of specific actors, collective power can 
also be "productive" in Barnett and Duvall's sense. IGOs often facilitate norm entrepreneurship and diffusion. Looking at Sweden, Björkdahl (2007:541) argues, "Small states in particular rely on international organizations and multilateral settings for their norm promoting activities."

For this reason, small states have been enthusiastic joiners and builders of institutions. "Small states try to minimize the costs of conducting foreign policy by initiating more joint action and targeting multi-actor fora" (Neumann and Gstöhl 2006:12). IGOs provide a seat at the table, and in many cases, they also provide a vote, which might be formally equal to the vote of a great power. Panke (2012) demonstrates that small states are able to deploy that vote, along with dedicated expertise in the institutions that matter most to them, to gain greater influence in international negotiations. Small states commit to play by the rules (and subtly shape them) because they believe the institution is likely to advance their national interests. There are numerous examples where small states play outsize roles within global, regional, and issuespecific IGOs. Citizens of small states often serve as influential heads of IGOs like the United Nations. Small states have often been large contributors of foreign aid and participants in peacekeeping missions, where Nordic states have exercised significant influence on doctrines (Jakobsen 2007). Estonia has made a point of meeting NATO guidelines for military spending, even as most European members fell well short of their targets. Itself a victim of major cyberattacks, Estonia hosts the NATO center on cybersecurity. Inside the EU, it has worked to block policies that it fears would enhance energy dependency on Russia (Crandall 2014; Hamilton 2008:119). Small states have been enthusiastic supporters of the European Union; in several of its decision-making bodies, they have formally equal representation. By actively engaging with EU Commissioners, small states in Europe have at times sought to use the Commission bureaucracy as a mediator or advocate with the larger powers (Thorhallsson 2000). By demonstrating their own willingness to play by institutional rules, small members like Luxembourg can credibly condemn larger states for hypocrisy and double standards (Hey 2003b). The combination of rules and negotiating strategies can help small states minimize the effects of asymmetry. For example, Antigua and Barbuda won its case against the United States at every level of the World Trade Organization. As one scholar (Jackson 2012:382) notes, "When a very small state such as Antigua employs thoughtful strategies and follows the procedures laid out by the institution, it can gain bargaining leverage." 
Global organizations facilitate access to a broad audience including larger powers. However, they might provide less freedom of action for smaller states, which in response have built regional organizations to serve as forums for policy coordination and as joint mechanisms to press their agendas. Given its European focus, the literature on small states often points to small-state led organizations in Northern Europe that facilitate Scandinavian and Nordic cooperation (Ingebritsen 2002; Jakobsen 2007). The Finnish Northern Dimension Initiative promoted national interests in the guise of pan-European interests (Arter 2000). Though the Gulf Cooperation Council was long seen as a tool for Saudi Arabia to corral its small neighbors, Qatar and the United Arab Emirates have more recently achieved strong positions within the forum (Kamrava 2013:32-40). Small states, notably Singapore, have been major players in ASEAN. Small states have also created their own groupings focused on gaining world attention or changing policies on issues of specific importance. Initially, much of small states' diplomatic attention in this vein was economic. The Caribbean Community brought together very small economies with the goal of increasing resilience to global economic fluctuations (BraveboyWagner 2008). Small states were strong advocates for the notion of commodity producer associations under a New International Economic Order in the 1970s (Rothstein 1979; White 1975). More recently, given their unique vulnerability, small island states have coalesced around the threat of climate change in order to organize a project of global scope, with deep economic ramifications for established and emerging powers. Their success has been partial. They achieved a special status for "small island developing states," and have used "theatrical interventions" and "grandstand tactics" to shame the United States into a change of position. "It is the vulnerability of small states that sets them apart from political wrangling and gives them a natural leadership role" (Benwell 2011:207). They rely on collective power to amass votes and give greater resonance to arguments centered on survival and morality. Finally, small states have been able to gain the diplomatic support of other small states to advance their own particular causes internationally. In this case, the supportive countries do not necessarily have a direct benefit for their support, though they might hope for reciprocal support or indirect benefits. In the 1970s, Panama gained the support of numerous small and medium states in support of its position on control of the Panama Canal (Long 2014, 2015). Near-unanimous Latin American diplomatic pressure and a threatened boycott of the Summit of the Americas added pressure on the United States to alter its policies on Cuba. 
To return to Dahl's framework, collective power's base is a small state's relationships with other states. This differs from derivative power both in terms of the partner and because collective-power partners are not singly able to assist the state in achieving its objectives. Inside institutions, rules that mediate relations between states could serve as a base of power. For example, voting rights give small states at least a modicum of power in situations where their vote could tip the balance or is needed for a coalition. If unanimity is required or strongly preferred by an organization, a vote can allow a small state the power to stop or modify initiatives favored by great powers. This form of power is not unique to small states; clearly, the Security Council veto is a base of power for the permanent five. With social relations, including rules, forming the base of collective power, the means concern the application of those relations. The individual small state gains power by acting through the organization or institution, and by positing its own goals as in the institutional interest. Small states might be more able to accomplish this sleight of hand than great powers, either because they can be seen as useful intermediaries between great powers or because their size means that concessions to them are minor from a great-power point of view. In practice, states exercising collective power will deploy a number of means. Important among these are agenda-setting, the definition of mutual interests, and persuasion.

As with other forms of power, scope and amount are heavily dependent on context. The scope of collective power, understood as the range of behavior that could be changed by the small power, is potentially great. If small states can influence institutional rules and procedures, then the effects of these rules can be "sticky" and perhaps unforeseen (Ikenberry 1998), just as for rules shaped by greater powers. Ad hoc coalitions of small states will typically have a narrower scope due to the difficulty of building and maintaining a consensus between disparate states. Holding a group together on one issue is more feasible than across a broad agenda. The amount of collective power - the delta in the probability of changed behavior - is likely to be low when dealing with a great power. When fundamental interests are at play, in the near term, a great power is likely to override a coalition of small states. However, these coalitions can exercise meaningful influence in other ways. First, they may nudge other states toward the desired position of the small state, even where they cannot force a reversal. Secondly, when other states' interests are diffuse or poorly defined, they can play a significant role in affecting agendas and influencing definitions of interests. Finally, coalitions of small states can signal limitations 
or vetoes on larger states' actions. In this case the sheer number of small states can give them a legitimacy that outstrips their share of world population. This is notable in what many perceive as the global legitimacy of the International Criminal Court, though nearly two-thirds of the world's population resides in non-member states (Deitelhoff and Wallbott 2012:350-55).

\section{Conclusions}

In many respects, today's world is a more hospitable place for small states. Their survival and territorial integrity are rarely threatened; many thrive economically. Has comity translated into influence? This article argues that the implied focus on resource-based and compulsory power has limited IR scholars' ability to assess small states' power. Small states may specialize in less conventional bases and means, drawing on institutional, structural, and productive facets of power, as well as nontraditional forms of compulsory power. This article has sought to develop that approach to connect work on small states to broader debates about power in IR. Incorporating other analyses of power, especially Barnett and Duvall's taxonomy, with Dahl's classic framework, the article proposes three ways in which small states exercise power through particular-intrinsic power, derivative power, and collective power. These forms of power are not exclusive to states under some threshold of material capabilities. In fact, these types of power are perhaps more important for all states today; military force is less acceptable and salient, interdependence is greater, and norms and institutions are more important. However, the weaker the state in terms of traditionally salient military and economic resources, the more it must specialize in and develop these diverse approaches to power. Small states' power might look a bit different, but on a fundamental level it remains power.

Rich and poor small states - or for that matter, territorially small and expansive, but lowpopulation states - differ in ways that complicate strict comparison. However, these states' attempts to exert influence share important similarities at a higher level of abstraction. To overcome their relative deficits in material resources, these states turn to particular-intrinsic, derivative, or collective forms of power. Though not unique to small states, specializing in particular material and ideational resources can increase a small state's power. These states must also emphasize power based on relationships in order to leverage the power of larger allies and to enhance their position and influence in international society through coalitions and institutions. Two of these three forms indicate that small states are less likely to pursue their aims 
individually. This suggests that while small states themselves are not necessarily comparable, there might be good reasons to compare their actions and relationships. Further work on small states' power might usefully turn to the challenge of contextualization: when are small states most likely to turn to a certain type of power? Returning to the bases and means of small-state power, along with the scope and amount of its effects, is one promising approach. 


\section{References}

Acharya, Amitav. (2008) Singapore's Foreign Policy : The Search for Regional Order. Singapore: World Scientific.

Alesina, Alberto, and Enrico Spolaore. (2003) The Size of Nations. Cambridge, Mass.: MIT Press. Armstrong, Harvey W, and Robert Read. (1998) Trade and Growth in Small States: The Impact of Global Trade Liberalisation. The World Economy 21(4):563-85.

Arter, David. (2000) Small State Influence within the EU: The Case of Finland's 'Northern Dimension Initiative'. JCMS: Journal of Common Market Studies 38(5):677-97.

Ayoob, Mohammed. (2003) Inequality and Theorizing in International Relations: The Case for Subaltern Realism. International Studies Review 4(3):27-48.

Bachrach, Peter, and Morton S Baratz. (1962) Two Faces of Power. American Political Science Review 56:947-52.

Bailer, Stefanie. (2004) Bargaining Success in the European Union: The Impact of Exogenous and Endogenous Power Resources. European Union Politics 5(1):99-123.

Baldacchino, Godfrey. (2009) Thucydides or Kissinger? A Critical Review of Smaller State Diplomacy. In The Diplomacies of Small States: Between Vulnerability and Resilience, eds. Andrew F. Cooper and Timothy M. Shaw, 21-40. New York: Palgrave Macmillan.

Baldwin, David A. (1979) Power Analysis and World Politics: New Trends Versus Old Tendencies. World Politics 31(2):161-94.

Barnett, Michael, and Raymond Duvall. (2005) Power in International Politics. International Organization 59(1):39-75.

Benwell, Richard. (2011) The Canaries in the Coalmine: Small States as Climate Change Champions. The Round Table 100(413):199-211.

Berenskoetter, Felix. (2007) Thinking About Power. In Power in World Politics. Ed. Felix Berenskoetter and M.J. Williams, 1-22. New York: Routledge.

Björkdahl, Annika. (2008) Norm Advocacy: A Small State Strategy to Influence the EU. Journal of European Public Policy 15(1):135-54.

--—. (2007) Swedish Norm Entrepreneurship in the UN. International Peacekeeping 14(4):538-52.

Bosco, David L. (2014) Rough Justice : The International Criminal Court in a World of Power Politics. New York: Oxford University Press. 
Bower, Adam. (2015) Norms without the Great Powers: International Law, Nested Social Structures, and the Ban on Antipersonnel Mines. International Studies Review 17(3): 347-373.

Braveboy-Wagner, Jacqueline. (2010) Opportunities and Limitations of the Exercise of Foreign Policy Power by a Very Small State: The Case of Trinidad and Tobago. Cambridge Review of International Affairs 23(3):407-27.

---. (2008) Small States in Global Affairs : The Foreign Policies of the Caribbean Community (Caricom). New York: Palgrave Macmillan.

- - - (2003) The Foreign Policies of the Global South : Rethinking Conceptual Frameworks. Boulder, Colo.: Lynne Rienner.

Braveboy-Wagner, Jacqueline Anne, and Michael T. Snarr. (2003) Assessing Current Conceptual and Empirical Approaches. In The Foreign Policies of the Global South : Rethinking Conceptual Frameworks. Ed. Jacqueline Anne Braveboy-Wagner, 13-30. Boulder, Colo.: Lynne Rienner.

Browning, Christopher S. (2006) Small, Smart and Salient? Rethinking Identity in the Small States Literature. Cambridge Review of International Affairs 19(4):669-84.

Carney, Christopher P. (1989) International Patron-Client Relationships: A Conceptual Framework. Studies in Comparative International Development 24(2):42-55.

Checkel, Jeffrey T. (1998) The Constructive Turn in International Relations Theory. World Politics 50(2):324-48.

Chong, Alan. (2010) Small State Soft Power Strategies: Virtual Enlargement in the Cases of the Vatican City State and Singapore. Cambridge Review of International Affairs 23(3):383-405.

Chong, Alan, and Matthias Maass. (2010) Introduction: The Foreign Policy Power of Small States. Cambridge Review of International Affairs 23(3):381-82.

Cooley, Alexander. (2014) Great Games, Local Rules : The New Great Power Contest in Central Asia. New York: Oxford University Press.

Copeland, Dale C. (2000) The Origins of Major War. Ithaca, N.Y.: Cornell University Press.

Cox, Robert. (1983) Gramsci, Hegemony and International Relations : An Essay in Method. Millennium: Journal of International Studies 12(2):162-75.

Cox, Robert W. (1981) Social Forces, States and World Orders: Beyond International Relations Theory. Millennium: Journal of international Studies 10(2):126-55.

Crandall, Matthew. (2014) Soft Security Threats and Small States: The Case of Estonia. Defence Studies 14(1):30-55.

Dahl, Robert A. (1957) The Concept of Power. Behavioral Science 2(3):201-15. 
Darnton, Christopher. (2012) Asymmetry and Agenda-Setting in US-Latin American Relations: Rethinking the Origins of the Alliance for Progress. Journal of Cold War Studies 14(4): 55-92.

DeConde, Alexander. (1992) Ethnicity, Race, and American Foreign Policy : A History. Boston: Northeastern University Press.

Deitelhoff, Nicole, and Linda Wallbott. (2012) Beyond Soft Balancing: Small States and CoalitionBuilding in the ICC and Climate Negotiations. Cambridge Review of International Affairs 25(3):345-66.

Desch, Michael C. (1993) When the Third World Matters : Latin America and United States Grand Strategy. Baltimore: Johns Hopkins University Press.

Dominguez, Jorge. (1989) To Make a World Safe for Revolution : Cuba's Foreign Policy. Cambridge, Mass.: Harvard University Press.

East, Maurice A. (1973) Size and Foreign Policy Behavior: A Test of Two Models. World Politics 25(4):556-76.

Easterly, William, and Aart Kraay. (2000) Small States, Small Problems? Income, Growth, and Volatility in Small States. World Development 28(11):2013-27.

Elman, Miriam Fendus (1995) The Foreign Policies of Small States: Challenging Neorealism in Its Own Backyard. British Journal of Political Science. 25(2):171.

Escudé, Carlos. (1998) An Introduction to Peripheral Realism and Its Implications for the Interstate System. In International Relations Theory and the Third World. Ed. Stephanie G. Neuman. New York: St. Martin's Press.

Fox, Annette Baker. (1959) The Power of Small States : Diplomacy in World War li. Chicago, III.: University of Chicago Press.

Friedman, Max Paul, and Tom Long. (2015) Soft Balancing in the Americas: Latin American Opposition to U.S. Intervention, 1898-1936. International Security 40(1):120-56.

Gleijeses, Piero. (2008) The View from Havana : Lessons from Cuba's African Journey, 1959-1976. In In from the Cold : Latin America's New Encounter with the Cold War. Eds. Gilbert M. Joseph and Daniela Spenser. Durham: Duke University Press.

Goetschel, Laurent. (1998) The Foreign and Security Policy Interests of Small States in Today's Europe. In Small States Inside and Outside the European Union. Ed., Laurent Goetschel, 13-31. Springer.

Guzzini, Stefano. (2005) The Concept of Power: A Constructivist Analysis. Millennium-Journal of International Studies, 33(3):495-521. 
Hamilton, Daniel S. (2008) The Baltics: Still Punching above Their Weight. Current History 107. Handel, Michael I. (1981) Weak States in the International System. London, England: Frank Cass. Henrikson, Alan K. (2001) A Coming 'Magnesian’age? Small States, the Global System, and the International Community. Geopolitics 6(3):49-86.

Hey, Jeanne A. K. (2003a) Introducing Small State Foreign Policy. In Small States in World Politics : Explaining Foreign Policy Behavior. Ed. Jeanne A. K. Hey. Boulder: Lynne Rienner.

- - . (2003b) Luxembourg: Where Small Works (and Wealthy Doesn't Hurt). In Small States in World Politics : Explaining Foreign Policy Behavior. Ed. Jeanne A. K. Hey, pp. 75-94. Boulder: Lynne Rienner.

Hopf, Ted. (1998) The Promise of Constructivism in International Relations Theory. International Security 23(1):171-200.

Huish, Robert. (2011) Punching above Its Weight: Cuba's Use of Sport for South-South Co-Operation. Third World Quarterly 32(3):417-33.

Ikenberry, G John. (1998) Constitutional Politics in International Relations. European Journal of International Relations 4(2):147-77.

Ingebritsen, Christine. (2004) Learning from Lilliput: Small States and EU Expansion. Scandinavian Studies 76(3):369-84.

---. (2000) The Nordic States and European Unity. Ithaca, N.Y.: Cornell University Press.

- - . (2002) Norm Entrepreneurs : Scandinavia's Role in World Politics. Cooperation and Conflict 37(1):11-23.

---. (2006) Scandinavia in World Politics. Rowman \& Littlefield.

Jackson, Sarita. (2012) Small States and Compliance Bargaining in the WTO: An Analysis of the Antigua-US Gambling Services Case. Cambridge Review of International Affairs 25(3):367-85. Jakobsen, Peter Viggo. (2009) Small States, Big Influence: The Overlooked Nordic Influence on the Civilian ESDP. JCMS: Journal of Common Market Studies 47(1):81-102.

- - . (2007) Still Punching above Their Weight? Nordic Cooperation in Peace Operations after the Cold War. International Peacekeeping 14(4):458-75.

Jiménez, Marguerite Rose. (2013) Polio and the Politics of Policy Diffusion in Latin America. PhD dissertation. Washington: American University.

-- - (2011). Cuba's pharmaceutical advantage. NACLA Report on the Americas, 44(4): 26-29,43.

Jourde, Cédric. (2007) The International Relations of Small Neoauthoritarian States: Islamism, Warlordism, and the Framing of Stability. International Studies Quarterly 51(2):481-503. 
Kamrava, Mehran. (2013) Qatar : Small State, Big Politics. Ithaca, N.Y.: Cornell University Press. Katzenstein, P. (1985) Small States in World Markets. Ithaca, N.Y.: Cornell University Press.

Keohane, Robert O, and Joseph S Nye Jr. (1973) Power and Interdependence. Survival 15(4):158-65. Keohane, Robert O. (1971) The Big Influence of Small Allies. Foreign Policy 2:161-82.

-_- (1969) Lilliputians' Dilemmas: Small States in International Politics. International Organization 23(2):291-310.

Keohane, Robert O., and Joseph S. Nye. (1977) Power and Interdependence : World Politics in Transition. Boston: Little, Brown.

Kirk, John M. (2009) Cuban Medical Internationalism and Its Role in Cuban Foreign Policy. Diplomacy \& Statecraft 20(2):275-90.

Klotz, Audie. (1995) Norms Reconstituting Interests: Global Racial Equality and US Sanctions against South Africa. International Organization 49(3):451-78.

Kleiboer, Marieke. (1996) Understanding Success and Failure of International Mediation. Journal of Conflict Resolution 40(2): 360-389

Krasner, Stephen D. (1976) State Power and the Structure of International Trade. World Politics 28(3):317-47.

Kronsell, Annica. (2002) Can Small States Influence EU Norms?: Insights from Sweden's Participation in the Field of Environmental Politics. Scandinavian Studies 74(3):287-304.

Lake, David A. (2009) Hierarchy in International Relations. Ithaca, N.Y.: Cornell University Press.

Long, Tom. (2016) It's Not the Size, It's the Relationship: From 'Small States' to Asymmetry. International Politics.

---. (2015) Latin America Confronts the United States: Asymmetry and Influence. Cambridge University Press.

- - . (2014) Putting the Canal on the Map: Panamanian Agenda-Setting and the 1973 Security Council Meetings. Diplomatic History 38(2):431-55.

Lukes, Steven. (1974) Power: A Radical View. London: Macmillan.

Maass, Matthias. (2009) The Elusive Definition of the Small State. International Politics 46(1):65-83. Mack, Andrew. (1975) Why Big Nations Lose Small Wars: The Politics of Asymmetric Conflict. World Politics 27(2):175-200.

Manners, Ian. (2002) Normative Power Europe: A Contradiction in Terms? JCMS: Journal of Common Market Studies 40(2):235-58. 
Maoz, Zeev. (1989) Power, Capabilities, and Paradoxical Conflict Outcomes. World Politics 41(2):239-

66.

Mearsheimer, John J. (2001) The Tragedy of Great Power Politics. New York: Norton.

Mearsheimer, John J. , and Stephen M. Walt. (2007) The Israel Lobby and U.S. Foreign Policy. New York: Farrar, Straus and Giroux.

Mohammed, Debbie A. (2013) The CARIFORUM-EU Economic Partnership Agreement: Impediment or Development Opportunity for CARICOM SIDS? In The Diplomacies of Small States: Between Vulnerability and Resilience. Eds. Andrew F. Cooper and Timothy M. Shaw. New York: Palgrave Macmillan.

Moon, Bruce E. (1983) The Foreign Policy of the Dependent State. International Studies Quarterly 27(3):315-40.

Morgenthau, Hans J., and Kenneth W. Thompson. (1985) Politics among Nations : The Struggle for Power and Peace. New York: Knopf.

Neumann, Iver, and Sieglinde Gstöhl. (2006) Lilliputians in Gulliver's World? In Small States in International Relations. Eds. Christine Ingebritsen, Iver Neumann, Sieglinde Gstöhl and Jessica Beyer, 3-36. Seattle: University of Washington Press.

Newhouse, John. (2009) Diplomacy, Inc. : The Influence of Lobbies on U.S. Foreign Policy. Foreign Affairs 88(3):73-92.

Nye, Joseph S. (2004) Soft Power: The Means to Success in World Politics. New York: Public Affairs.

Ólafsson, Björn G. (1998) Small States in the Global System : Analysis and Illustrations from the Case of Iceland. Brookfield, Vt: Ashgate.

Panke, Diana. (2012) Dwarfs in International Negotiations: How Small States Make Their Voices Heard. Cambridge Review of International Affairs 25(3):313-28.

- - . (2011) Small States in EU Negotiations Political Dwarfs or Power-Brokers? Cooperation and Conflict 46(2):123-43.

-- - (2010) Small States in the European Union: Coping with Structural Disadvantages. Brookfield, Vt.: Ashgate.

Persaud, Randolph B. (2001) Counter-Hegemony and Foreign Policy : The Dialectics of Marginalized and Global Forces in Jamaica. Albany, N.Y.: State University of New York Press.

Rickli, Jean-Marc. (2008) European Small States' Military Policies after the Cold War: From Territorial to Niche Strategies. Cambridge Review of International Affairs 21(3):307-25. 
Risse-Kappen, Thomas. (1995) Cooperation among Democracies : The European Influence on U.S. Foreign Policy. Princeton Studies in International History and Politics. Princeton, N.J.: Princeton University Press.

Ropp, Stephen C., and Kathryn Sikkink. (1999) The Power of Human Rights: International Norms and Domestic Change. New York: Cambridge University Press.

Rostoks, Toms. (2010) Small States, Power, International Change and the Impact of Uncertainty. In Small States in Europe: Challenges and Opportunities. Ed. Robert Steinmetz and Anders Wivel, 87-101. Farnham, England: Ashgate.

Rothstein, Robert L. (1979) Global Bargaining: UNCTAD and the Quest for a New International Economic Order. Princeton, N.J.: Princeton University Press.

Rothstein, Robert L. (1968) Alliances and Small Powers. New York: Columbia University Press.

Shoemaker, Christopher C., and John W. Spanier. (1984) Patron-Client State Relationships : Multilateral Crises in the Nuclear Age. New York: Praeger.

Sikkink, Kathryn. (2007) Mixed Signals : U.S. Human Rights Policy and Latin America. Ithaca, N.Y.: Cornell University Press.

Steinmetz, Robert, and Anders Wivel. (2010) Small States in Europe: Challenges and Opportunities. Farnham, England: Ashgate.

Strange, Susan. (1987) The Persistent Myth of Lost Hegemony. International Organization 41(4):55174.

Sullivan, Patricia L. (2007) War Aims and War Outcomes: Why Powerful States Lose Limited Wars. Journal of Conflict Resolution 51(3):496-524.

Thomson, Robert. (2008) National Actors in International Organizations the Case of the European Commission. Comparative Political Studies 41(2):169-92.

Thorhallsson, Baldur. (2000) Small States in the European Union. Aldershot, England: Ashgate. Thorhallsson, Baldur, and Anders Wivel. (2006) Small States in the European Union: What do We Know and What Would We Like to Know? Cambridge Review of International Affairs 19(4):651-68.

Tickner, Arlene. (2007) Intervención por Invitación: Claves de la Política Exterior Colombiana y de sus Debilidades Principales [Intervention by Invitations: Keys of Colombian Foreign Policy and its Principal Weaknesses]. Colombia Internacional 65:90-111.

Vital, David. (1967) The Inequality of States: a Study of the Small Power in International Relations. Oxford, UK: Clarendon Press. 
Vleck, William. (2009) The Caribbean Confronts the OECD: Tax Competition and Diplomacy. In The Diplomacies of Small States: Between Vulnerability and Resilience. Eds. Andrew F. Cooper and Timothy M. Shaw. New York: Palgrave Macmillan.

Waage, Hilde Henriksen. (2007) The 'Minnow'and the 'Whale': Norway and the United States in the Peace Process in the Middle East. British Journal of Middle Eastern Studies 34(2): 157-176.

Waltz, Kenneth. (1979) Theory of International Politics. Reading, Mass.: Addison-Wesley.

Wendt, Alexander E. (1987) The Agent-Structure Problem in International Relations Theory. International Organization 41(3):335-70.

White, Robin C. A. (1975) A New International Economic Order. The International and Comparative Law Quarterly 24(3):542-52.

Wivel, Anders. (2010) From Small State to Smart State: Devising a Strategy for Influence in the European Union. In Small States in Europe: Challenges and Opportunities, Ed. Robert Steinmetz and Anders Wivel, 15-30. Farnham, England: Ashgate. 